\title{
Analysis Of The Factors That Have Influence On Tuberculosis (Tb) Patients' Self Efficacy And Medical Behavior In Garut Regency
}

Angga Irawan ${ }^{1}$

${ }^{1}$ STIKES Sari Mulia Banjarmasin

Email: angga_irawan10@yahoo.co.id

Laili Rahayuwati ${ }^{2}$

${ }^{2}$ Nursing Faculty of padjajaran University

laily@gmail.com

Dessy Indra Yani ${ }^{2}$

${ }^{2}$ Nursing Faculty of padjajaran University

Dessy_indra@gmail.com

\begin{abstract}
Objective: the influence of demographic, knowledge, emotional condition, motivation, and family support factors on both self efficacy and therapeutic behavior of those patients with TB in Garut District.

Method: The study associative analytic research using cross sectional approach the amount of respondents was was 305 , selected by a proportionate random sampling. Data collection was carried out for 3 weeks. Data collection method used a questionnare, and the data obtained was then analyzed by a logistic regression.

Results: The factors that have influence of both self-efficacy and medical behaviors were family support ( $\mathrm{p}$ value $=0.000$ ) and medical motivation $(\mathrm{p}$ value $=0.000)$. The research results showed that the most influential factor on TB patients' medical behaviors was medical motivation ( $\mathrm{p}$ value $=0.000)$.
\end{abstract}

Conclusion: Those factors that influenced both self efficacy and therapeutic behavior of TB patients in Garut District were family support and motivation of treatment.

Keywords: Tuberculosis, Behavior, Self-Efficacy, Motivation, Family Support

\section{INTRODUCTION}

Tuberculosis (TB) is a contagious disease that is still a problem in the health world until today. According to World Health Organization (WHO, 2012) there are 8.6 million cases of tuberculosis and among them 1.3 million people died. Based on Global Tuberculosis Control in 2013 the incidence of $\mathrm{TB}$ in Indonesia with the number of TB cases as much as $0.38-0.54$ million cases with the number of new cases of positive BTA as much as 202,301. West Java has a number of TB cases in 2012 with 47,827 cases of cases of TB BTA (+) of 34,123 cases and case finding of 7,135 cases, while in 2013 it increased by $0.7 \%$. $^{1,2}$ The incidence of tuberculosis in Garut regency in 2012 has a TB case number of $2.4 \%$, and in the year 2013 the number of TB cases as 6,231 cases, such as suspect tuberculosis as many as 5,237 cases, TB in children as many as 171 cases, 
and the discovery of new cases 823 cases. While the achievement of global targets, the success of treatment reaches $90 \%$ and the success rate of treatment reaches $85 \%$ of the number of patients with TB ${ }^{1}$. An effective strategy for TB control that can be implemented is the DOTS strategy (Direct Observed Treatment Short Course) that successfully achieves the target of TB treatment success by $90 \%$. $^{2,9,12 \text {, }}$

Efforts to increase the achievement of TB tackling targets nationally, it is necessary to strive for health equity strategies and strategies by utilizing all the potentials, whether in health, non-health and society itself. While TB prevention efforts at provincial level in its implementation, implemented by forming Gerdunas TB (National Integrated Movement of Tuberculosis Control) consisting of steering team and technical team as implementation of TB program. Implementation at the district level of the TB program is implemented by the District Health Office, with aspects of the management of TB programs implemented at the Puskesmas, Hospitals, BP4 (Balai Pengobatan Lung Disease) and private practice doctors. $^{3,5}$

The success of treatment is influenced by internal and external factors. Based on the research results of Gebremariam (2010) internal factors that influence the success of TB treatment, namely: 1) facilities factors covering the availability of continuous treatment coverage, education of health workers, and adequate OAT, 2) patient factors including knowledge, awareness, to heal, and personal hygiene, 3) family, community and environmental factors. While the external factors of the success of TB control program. ${ }^{2,5,8}$

Behavior is a response or a person's reaction to stimulus stimuli from the outside. Behavior changes will occur if there is a change in health status from a healthy area to a sick area in order to get health status back. 3,4, Behavior of the sick or tired of health problems, to get healing or solving health problems is called health seeking behavior. Utilization of health services include three determinants of health behavior that is predisposing, enabling and need factors. These three factors illustrate the individual's decision to use health services, the first factor being: predisposing factors describe the individual characteristics attached to him and vary the use of health services. Predisposing factors include demographic factors (age, gender, marital status), social factors (education, occupation, ethnicity) and health belief factors (knowledge and beliefs). ${ }^{4}$ The second factor is enabling factors indicating the ability of individuals to obtain services and is a condition that makes individuals able to perform actions to meet their needs for health services. Enabling factors consist of family resources (family income, health insurance, family support) and community resources (availability and accessability to TB services). The third factor is the need factors 
is the basis and direct stimulus to use the service. Needs refer to perceived need and clinical evaluation by health care providers. ${ }^{4,5,7}$

Various studies have suggested that sociodemographic characteristics that affect client delays are affected by age and Furthermore, based on research Diez et. al (2004) states that the age factor, whether married or widowed women affect the delay in seeking health services. TB clients residing in rural areas were more influential on client delays than in urban areas. ${ }^{6,8,11}$

\section{METHODS}

The type of this research is associative analytic research using Cross Sectional approach. Sampling in this study was done with simple technique because the population amounted to 871 people.

The research was conducted in Garut regency, the reason for choosing the location where the research is found the problem of TB according to data or information in Health Department. Univariate analysis by presenting the data in accordance with the type of data. Ordinal data is used for the median, interquartile range and confidence intervals while the categorical data can only explain the value or frequency and percentage of each group. Further analysis results presented include mean, standard deviation, minimum and maximum value, 95\% CI. Bivariate analysis was done by using Spearman Rank correlation test, bivariate analysis for independent variable with nominal data scale was performed by using Chi Square test, using $\alpha=0,05$, minimum and maximal value, 95\% CI. While multivariate analysis in this research use logistic regression analysis.

\section{RESULT}

The results of this study describes the results of research on the effect of self efficacy and treatment behavior on TB clients in Garut regency.

Data was collected from February 8 to 29 February 2016, with 305 TB clients. Number of clients who experience drop out during the research process does not exist, because researchers do by way of coming to the client directly, so the total results of this study as many as 305 respondents. This research was conducted in 5 health centers in Garut regency namely; Puskesmas Tarogong DTP, Bayombong, Rancasalak, Leuwigoong, Leles DTP.

Table 1 Distribution of Respondents Based on age, treatment knowledge, emotional state of treatment, family support in treatment, medication motivation, self efficacy treatment and treatment behavior in Garut District 2016 ( $\mathrm{n}=305$ TB Client).

\begin{tabular}{lccccc}
\hline \multicolumn{1}{c}{ Variabel } & $\begin{array}{c}\text { Possible } \\
\text { score }\end{array}$ & $\begin{array}{c}\text { M } \\
\text { ini } \\
\text { m } \\
\text { al }\end{array}$ & $\begin{array}{c}\text { Mak } \\
\text { sima } \\
1\end{array}$ & $\begin{array}{c}\text { Med } \\
\text { ian }\end{array}$ & $\begin{array}{c}\text { Inter } \\
\text { quar } \\
\text { tile } \\
\text { rang } \\
\text { e }\end{array}$ \\
\hline Usia & & 14 & 66 & 32 & 18 \\
Medical & $0-19$ & 9 & 19 & 17 & 3 \\
Knowledge & & & & & \\
\hline $\begin{array}{l}\text { Motivation } \\
\text { Treatment }\end{array}$ & $10-40$ & 27 & 40 & 33 & 4 \\
$\begin{array}{l}\text { Emotional } \\
\text { state Medicine }\end{array}$ & $13-52$ & 23 & 46 & 34 & 6 \\
$\begin{array}{l}\text { Family } \\
\text { Support in } \\
\text { Medicine }\end{array}$ & $32-128$ & 78 & 122 & 107 & 9 \\
\hline $\begin{array}{l}\text { Self efficacy } \\
\text { Behavioral }\end{array}$ & $12-48$ & 26 & 45 & 36 & 4 \\
Treatment & $6-24$ & 6 & 23 & 18 & 6 \\
\hline & & & & & \\
\hline
\end{tabular}


Table 2 it is known that the TB clients in Garut regency of West Java Province on average aged 32 years with the youngest age 14 years and the oldest 66 years with an IQR of 18. Knowledge of respondents between the average 17 with the lowest value 9 and the highest 19 for IQR score 3. Treatment motivation is an internal impulse with an average value of 33 and the lowest value 27 and highest motivation of treatment of respondents 40 with IQR value 4. Emotional situation of client respondents experienced in response to TB disease is 34 with average average respondents experiencing mild problem 23 and tend to high 46 with IQR 6. Support family of treatment with average 107. Lowest score 78 and highest 112 with IQR value 9 . Self efficacy treatment with average 107, lowest score 26 and highest 45 with the value of IQR 4. While the behavior of TB client treatment of the number 305 known that the highest value of 45 and the lowest 23 with an average value of 18 and IQR value 6.

Table 2 Effect of Sosiodemography on Self-efficacy and Treatment Behavior of TB Client in Garut Regency Year 2016 ( $n=305$ TB Client).

\begin{tabular}{lll}
\hline Variabel & $\begin{array}{l}\text { Self } \\
\text { efficacy } \\
\text { Treatment }\end{array}$ & $\begin{array}{c}\text { Behavior } \\
\text { Treatment }\end{array}$ \\
\hline Age & $\begin{array}{l}\mathrm{p}=0,225 \\
\mathrm{r}=0,065\end{array}$ & $\begin{array}{l}\mathrm{p}=0,339 \\
\mathrm{r}=0,055^{1}\end{array}$ \\
Gender & $\mathrm{p}=0,724$ & $\mathrm{p}=0,637$ \\
& $\mathrm{r}=0,135$ & $\mathrm{r}=0,230^{2}$ \\
Level of & $\mathrm{p}=0,859$ & $\mathrm{p}=0,053$ \\
education & $\mathrm{r}=0,010$ & $\mathrm{r}=0,111^{1}$ \\
Marital status & $\mathrm{p}=0,010$ & $\mathrm{p}=0,143$ \\
$*$ & $\mathrm{r}=9,224$ & $\mathrm{r}=3,888^{2}$ \\
\hline Income & $\mathrm{p}=0,675$ & $\mathrm{p}=0,265$
\end{tabular}

\begin{tabular}{|c|c|c|}
\hline Variabel & $\begin{array}{l}\text { Self } \\
\text { efficacy } \\
\text { Treatment }\end{array}$ & $\begin{array}{l}\text { Behavior } \\
\text { Treatment }\end{array}$ \\
\hline & $\begin{array}{l}r=-0,024 \\
1\end{array}$ & $r=-0,064^{1}$ \\
\hline Work & $\begin{array}{l}p=0,717 \\
r=3,698 \\
2\end{array}$ & $\begin{array}{l}\mathrm{p}=0,213 \\
\mathrm{r}=8,353^{2}\end{array}$ \\
\hline $\begin{array}{l}\text { Ownership of } \\
\text { health } \\
\text { insurance }\end{array}$ & $\begin{array}{l}p=0,294 \\
r=3,714 \\
2\end{array}$ & $\begin{array}{l}\mathrm{p}=0,622 \\
\mathrm{r}=1,769^{2}\end{array}$ \\
\hline $\begin{array}{l}\text { Distance to } \\
\text { puskesmas }\end{array}$ & $\begin{array}{l}p=0,876 \\
r=-0,009 \\
1\end{array}$ & $\begin{array}{l}\mathrm{p}=0,029 \\
\mathrm{r}=-0,125^{1}\end{array}$ \\
\hline $\begin{array}{l}\text { The existence } \\
\text { of PMO }\end{array}$ & $\begin{array}{l}p=0,007 \\
r=-0,154 \\
1\end{array}$ & $\begin{array}{l}\mathrm{p}=0,465 \\
\mathrm{r}=-0,042\end{array}$ \\
\hline $\begin{array}{l}\text { Characteristics } \\
\text { of PMO }\end{array}$ & $\begin{array}{l}\mathrm{p}=0,663 \\
\mathrm{r}=0,822 \\
2\end{array}$ & $\begin{array}{l}\mathrm{p}=0,215 \\
\mathrm{r}=3,078^{2}\end{array}$ \\
\hline $\begin{array}{l}\text { Giving } \\
\text { Information }\end{array}$ & $\begin{array}{l}p=0,668 \\
r=0,025 \\
1\end{array}$ & $\begin{array}{l}\mathrm{p}=0,000 \\
\mathrm{r}=-0,315^{1}\end{array}$ \\
\hline Drug Delivery & $\begin{array}{l}p=0,977 \\
r=0,002 \\
1\end{array}$ & $\begin{array}{l}\mathrm{p}=0,530 \\
\mathrm{r}=0,036^{1}\end{array}$ \\
\hline
\end{tabular}

Description: ${ }^{1}=$ spearman test, ${ }^{2}=$ chi square test. Sociodemographic variables that become the dominant factor determining self efficacy and behavior of treatment are: marital status.

Table 3. Effect of Knowledge Level on Self-efficacy and Treatment Behavior of TB Client in Garut Regency Year 2016 ( $n=305$ TB Client).

\begin{tabular}{ccc}
\hline Variabel & $\begin{array}{c}\text { Self efficacy } \\
\text { Treatment }\end{array}$ & Behavioral Treatment \\
& $\mathrm{p}=0,813$ & $\mathrm{p}=0,160$ \\
Knowledge & $\mathrm{r}=-0,014^{1}$ & $\mathrm{r}=0,081^{1}$
\end{tabular}

Description: ${ }^{1}=$ spearman test, ${ }^{2}=$ chi square test.

Based on the results of the study note that the variable knowledge does not significantly influence the Self-efficacy $(\mathrm{p}$-value $=0.813)$ and Treatment Behavior $(\mathrm{p}$-value $=0.160)$ 
Table 4. The Influence of Emotional Behavior Against Selfefficacy and Treatment Behavior of TB Client in Garut Regency Year 2016 ( $n=305$ TB Client).

\begin{tabular}{cll}
\hline Variables & $\begin{array}{c}\text { Self efficacy } \\
\text { Treatment }\end{array}$ & $\begin{array}{c}\text { Behavioral } \\
\text { Treatment }\end{array}$ \\
\hline Emotional state & $\mathrm{p}=0,744$ & $\mathrm{p}=0,248$ \\
& $\mathrm{r}=0,019^{1}$ & $\mathrm{r}=-0,066^{1}$ \\
\hline
\end{tabular}

Description: ${ }^{1}=$ spearman test, ${ }^{2}=$ chi square test.

Based on the result of research, it is known that emotional state variable has no significant effect on self-efficacy ( $p$-value $=$ $0,744)$ and treatment behavior ( $\mathrm{p}$-value $=$ $0,248)$.

Table 5 Effect of Treatment Motivation Against Self-efficacy and Treatment Behavior of TB Client in Garut Regency Year $2016(n=305$ TB Client).

\begin{tabular}{lll}
\hline Variabel & $\begin{array}{c}\text { Self efficacy } \\
\text { Treatment }\end{array}$ & $\begin{array}{c}\text { Behavioral } \\
\text { Treatment }\end{array}$ \\
\hline Motivation & $\mathrm{p}=0,000$ & $\mathrm{p}=0,000$ \\
$*$ & $\mathrm{r}=0,575^{1}$ & $\mathrm{r}=0,654^{1}$ \\
\hline
\end{tabular}

Description: ${ }^{1}=$ spearman test, ${ }^{2}=$ chi square test.

Based on the results of the study it is known that the motivation variables significantly influence the Self-efficacy $(\mathrm{p}$-value $=0,000)$ and the Treatment Behavior ( $\mathrm{p}$-value $=$ $0,000)$.

Table 6 Influence of Family Support In Treatment Against Self-efficacy and Treatment Behavior of TB Client in Garut Regency Year 2016 ( $\mathrm{n}=$ 305 TB Client).

\begin{tabular}{cll}
\hline Variabel & $\begin{array}{c}\text { Self efficacy } \\
\text { Treatment }\end{array}$ & $\begin{array}{c}\text { Behavioral } \\
\text { Treatment }\end{array}$ \\
\hline Family support $*$ & $\mathrm{p}=0,000$ & $\mathrm{p}=0,000$ \\
& $\mathrm{r}=0,436^{1}$ & $\mathrm{r}=0,397^{1}$ \\
\hline
\end{tabular}

Keterangan $:{ }^{1}=$ uji spearman, ${ }^{2}=$ uji chi square

Based on the results of the study it is known that family support variables significantly influence Self-efficacy ( $p$-value $=0,000)$ and Treatment Behavior ( $\mathrm{p}$-value $=0,000$ ).
Table 7 Effect of Self-efficacy on TB Treatment Client Behavior in Garut Regency Year 2016 ( $n=305$ TB Client).

\begin{tabular}{lc}
\hline \multicolumn{1}{c}{ Variabel } & Perilaku Pengobatan \\
& \\
\hline $\begin{array}{l}\text { Self efficacy } \\
\text { treatment }\end{array}$ & $\mathrm{p}=0,000$ \\
& $\mathrm{r}=0,389^{1}$ \\
\hline
\end{tabular}

Keterangan $:{ }^{1}=$ uji spearman, ${ }^{2}=$ uji chi square

Based on the results of the study note that the variable Self-efficacy significantly influence the Treatment Behavior ( $\mathrm{p}$-value $=0,000$ ).

Table 8. Multivariate Analysis Based on Dominant Factors Determinants of Self Efficacy Treatment in District Garut Year 2016 ( $\mathrm{n}=305$ TB Client).

Multivariate Analysis

\begin{tabular}{|c|c|c|c|c|c|c|c|c|c|}
\hline & & \multirow[b]{2}{*}{ B } & \multirow[b]{2}{*}{ S.E. } & \multirow[b]{2}{*}{ Wald } & \multirow[b]{2}{*}{ df } & \multirow[b]{2}{*}{ Sig. } & \multirow[b]{2}{*}{$\begin{array}{c}\operatorname{Exp}( \\
\mathrm{B})\end{array}$} & \multicolumn{2}{|c|}{$\begin{array}{c}\text { 95\% C.I.for } \\
\text { EXP(B) }\end{array}$} \\
\hline & & & & & & & & $\begin{array}{c}\text { Lowe } \\
\mathrm{r}\end{array}$ & Upper \\
\hline \multirow[t]{4}{*}{$\begin{array}{l}\text { Ste } \\
\mathrm{p} 1^{\mathrm{a}}\end{array}$} & narriage & ,437 & $\begin{array}{r}, 21 \\
8\end{array}$ & 4,012 & 1 & $\begin{array}{r}, 04 \\
5\end{array}$ & 1,547 & 1,009 & 2,372 \\
\hline & $\begin{array}{l}\text { kat_sup } \\
\text { port }\end{array}$ & ,784 & $\begin{array}{r}32 \\
3\end{array}$ & 5,907 & 1 & $\begin{array}{r}, 01 \\
5\end{array}$ & 2,190 & 1,164 & 4,122 \\
\hline & $\begin{array}{l}\text { kat_mo } \\
\text { tivasi }\end{array}$ & 2,194 & $\begin{array}{r}32 \\
3\end{array}$ & $\begin{array}{r}46,22 \\
2\end{array}$ & 1 & $\begin{array}{r}, 00 \\
0\end{array}$ & 8,969 & 4,765 & 16,881 \\
\hline & $\begin{array}{l}\text { Consta } \\
\mathrm{nt}\end{array}$ & $\begin{array}{r}- \\
5,017\end{array}$ & $\begin{array}{r}, 63 \\
4 \\
\end{array}$ & $\begin{array}{r}62,62 \\
9 \\
\end{array}$ & 1 & $\begin{array}{r}, 00 \\
0 \\
\end{array}$ & ,007 & & \\
\hline
\end{tabular}

Variable (s) entered on step 1: marriage, support, and motivation.

Based on table 8 that the variables that affect the self efficacy of treatment is the variable of treatment motivation. The findings of this study indicate that all significant variables ( $\mathrm{p}$ value $<0.05$ ), but the variable of motivation is the most influential variable on self efficacy treatment of TB clients in Garut regency. 
Table 9 Multivariate Analysis Based on the Dominant Factors Determinants of Treatment Behavior in Garut District Year $2016(n=305$ TB Client).

\begin{tabular}{|c|c|c|c|c|c|c|c|c|c|}
\hline \multicolumn{10}{|c|}{ Multivariate Analysis } \\
\hline & & \multirow[b]{2}{*}{$\mathrm{B}$} & \multirow[b]{2}{*}{ S.E. } & \multirow[b]{2}{*}{ Wald } & \multirow{2}{*}{$\begin{array}{l}d \\
f\end{array}$} & \multirow[b]{2}{*}{ Sig. } & \multirow{2}{*}{$\begin{array}{c}\operatorname{Exp}(\mathrm{B} \\
)\end{array}$} & \multicolumn{2}{|c|}{$\begin{array}{l}\text { 95\% C.I.for } \\
\text { EXP(B) }\end{array}$} \\
\hline & & & & & & & & Lower & Upper \\
\hline \multirow[t]{4}{*}{$\begin{array}{l}\text { Step } \\
1^{\mathrm{a}}\end{array}$} & $\begin{array}{l}\text { Marri } \\
\text { age }\end{array}$ & 127 & ,228 & ,309 & 1 & ,579 & 1,135 & ,726 & 1,774 \\
\hline & $\begin{array}{l}\text { suppo } \\
\mathrm{rt}\end{array}$ & 083 & ,376 &, 049 & 1 &, 825 & 1,087 &, 520 & 2,270 \\
\hline & $\begin{array}{l}\text { kat_} \\
\text { mot } \\
\text { ivas } \\
\text { i }\end{array}$ & $\begin{array}{r}3,07 \\
8\end{array}$ & ,376 & 67,104 & 1 &, 000 & 21,707 & 10,394 & 45,330 \\
\hline & $\begin{array}{l}\text { Con } \\
\text { stan } \\
t\end{array}$ & $\begin{array}{r}- \\
4,75 \\
1\end{array}$ &, 620 & 58,735 & 1 & ,000 & ,009 & & \\
\hline \multirow[t]{3}{*}{$\begin{array}{l}\text { Step } \\
2^{\mathrm{a}}\end{array}$} & $\begin{array}{l}\text { Marri } \\
\text { age }\end{array}$ &, 128 & ,228 & ,314 & 1 &, 575 & 1,136 &, 727 & 1,774 \\
\hline & $\begin{array}{l}\text { kat_m } \\
\text { otivas } \\
\text { i }\end{array}$ & $\begin{array}{r}3,12 \\
6\end{array}$ & ,306 & 104,174 & 1 &, 000 & 22,791 & 12,504 & 41,543 \\
\hline & $\begin{array}{l}\text { Con } \\
\text { stan } \\
t\end{array}$ & $\begin{array}{r}- \\
4,70 \\
4\end{array}$ &, 579 & 65,983 & 1 &, 000 & ,009 & & \\
\hline \multirow[t]{2}{*}{$\begin{array}{l}\text { Step } \\
3^{\mathrm{a}}\end{array}$} & $\begin{array}{l}\text { kat_- } \\
\text { mot } \\
\text { ivas } \\
\text { i }\end{array}$ & $\begin{array}{r}3,14 \\
4\end{array}$ & ,305 & 106,078 & 1 & ,000 & 23,200 & 12,754 & 42,203 \\
\hline & $\begin{array}{l}\text { Con } \\
\text { stan } \\
t\end{array}$ & $-4,530$ & ,482 & 88,438 & 1 & ,000 & ,011 & & \\
\hline
\end{tabular}

Variable (s) entered on step 1: marriage, kat_ Based on the above table 4.9 shows that the motivation variable of treatment is significant because it has $\mathrm{p}$-value $=0,000<0,05$. This means that the variable level of medication motivation is the most influential variable on the behavior of TB treatment clients in Garut regency.

\section{DISCUSSION}

\section{Effect of Sosiodemography Against Self Efficacy Treatment of TB Clients.}

In the results of this research analysis there is a significant relationship between marital status with self efficacy treatment of TB clients. The results of this study in line with the research Delamater (2010) states that the majority of people who are married or living with their partners will have a good quality of life.

The results of this study showed that marital status on the percentage of married respondents showed better self efficacy treatment with a married status that is equal to $53.1 \%$, compared with unmarried $35.7 \%$ and the rest are widows $(\mathrm{p}$ value $=0.001>0.05)$.
The results of this study are not in line with the study of Theander and Unosson (2011), which shows that there is no influence between marital status and self-care behavior on clients with chronic illness. Similarly, studies conducted by. ${ }^{7,9,15}$ suggest that there is no influence between marital status with belief and treatment behavior in self-care in chronic patients.

\section{Effect of Knowledge Level on Self Efficacy} Treatment of TB Clients.

A person's level of knowledge is influenced by many factors including education, experience and facilities. Knowledge of self efficacy of treatment greatly affects a person to perform adequate treatment management and not the occurrence of drug withdrawal. Knowledge of TB clients enables them to know that their illness can be cured by taking medication regularly according to the instructions given. The results showed that there was no significant relationship between knowledge variables and self efficacy of TB client treatment ( $p$-value $=0.0895>0.05$ ) .

The Influence of Emotional Behavior Against Self Efficacy Treatment of TB Clients.

TB disease is a chronic disease experienced by clients who have to take treatment for 6-8 months. Adaptation or adaptation to any changes that occur due to the disease experienced is needed so that clients can live their lives normally.

Analysis of the relationship between emotional self efficacy in this study showed that there is no relationship between emotional state with self efficacy treatment (p-value $=0.74>0.05)$. The results of this study are not in line with the results of research conducted by Nelson et al (2007) mentions that the emotional state has a direct relationship with self efficacy.

\section{Influence of Family Support Against Self} Efficacy Treatment of TB Clients.

Based on Social Cognitive Theory Bandura (1994), social support that one form comes from the family is one source of information 
that supports the increase of self efficacy. The results showed that family support with self efficacy was known ( $\mathrm{p}$-value $=0.022<0.05$ ). There is a significant relationship between family support and self efficacy of TB client treatment.

The family plays an important role in providing support to $\mathrm{TB}$ clients in treatment. Research conducted Gaugler (2005), said that family involvement is very important for TB clients, with chronic diseases that require long-term care. Requires readiness and steadiness in the self to change his lifestyle and everyday behavior, so have confidence in his ability to care self. According to Bandura (2004) explains that a person's beliefs about their abilities will result in actions they want to achieve and have an impact on their lives.

\section{Effect of Self Efficacy Against TB Treatment Client Behavior.}

Self efficacy becomes a very important and useful construct in psychology, because self efficacy is related to one's ability to perform a variety of challenging behaviors including precautions and behavioral management for illness. Belief in one's own ability to do something (Bandura, 1977). People do not generally try to do something new unless they think they can do it. If one believes a new useful behavior (benefit perceived), but thinks the client is not able to do that (the barrier is felt), the possibility that it will not be done. The results of this study have a significant influence between family support variables and self efficacy treatment of TB clients (pvalue $=0.000>0.05$ ) .

\section{The Most Dominant Factors Influencing} Against Self Efficacy and Treatment Behavior of TB Clients.

Self efficacy becomes a very important and useful construct in psychology, because self efficacy is related to one's ability to perform a variety of challenging behaviors including precautions and behavioral management for illness.

\section{IMPLICATION OF RESEARCH RESULTS}

\section{Implications for Nursing Services}

The implications of the results of this study on nursing service is to prove that motivation, has contributed to treatment behavior. It can be used as a reference in formulating nursing care planning in an effort to improve treatment behavior in TB clients. Communication of a health officer or cadre in the provision of information or health education is paramount so that nursing practitioners can perform and improve health education or education related to treatment behavior programmed in every health care order and make health as the main intervention in providing nursing care to clients TB .

Nursing interventions in the form of health education about self efficacy are priorities in managing TB clients, besides nursing care for TB clients. Nursing care of the TB client is performed by the nurse by taking into account both the internal and external motivation aspects of treatment and support that the patient has for ease in achieving the goal.

\section{Nursing Education}

The implications of this study on nursing education is to provide a signal or sign to the educator that self efficacy and factors that contribute to the behavior of treatment needs to get specific attention so that students need to be equipped with the material self efficacy and the factors that influence it so that the curriculum review can be developed so that the material becomes part of the subject of the language that must be submitted to the nursing student so that the student as a nurse candidate is exposed by the knowledge and can apply in the practice of nursing care to the TB client.

\section{Nursing Research}

The results of this study can be used as scientific evidence that there is a contribution of medication motivation affect the behavior of TB client treatment, so it is necessary to develop advanced research with different design and methodology such as qualitative 
that can explore deeply how client experience in self efficacy and behavioral treatment of TB. ${ }^{10,11}$ Another advanced research that can be developed is to examine the influence of other factors not listed in this study, so as to enrich the results of research related to self efficacy and TB patient treatment behavior.

\section{REFERENCE}

1. Wulandari, L. (2012). Peran Pengetahuan terhadap Perilaku Pencarian Pengobatan Penderita Suspek TB Paru di Indonesia (Analisis Data Survei Pengetahuan, Sikap dan Perilaku Tuberkulosis Tahun 2010) (Doctoral dissertation, Tesis Fakultas Kesehatan Masyarakat Universitas Indonesia, Jakarta).

2. Andersen, R. (1995). Revisiting the Behavioral Model and Acces to Medical Care: Does it matter? Journal of Health and Social Behaviour, 36 (1), 1-10.

3. Kesehatan, D., \& RI, K. K. (2013). Riset Kesehatan Dasar. Jakarta: Badan Penelitian dan Pengembangan Kesehatan Departemen Kesehatan Republik Indonesia.

4. Kemenkes, R. I. (2011). Strategi nasional pengendalian TB di Indonesia 2010-2014. Kementrian Kesehatan RI Direktorat Jendral Pengendalian Penyakit dan Penyehatan Lingkungan.5

5. Fay, N., Garrod, S., \& Roberts, L. (2008). The fitness and functionality of culturally evolved communication systems. Philosophical Transactions of the Royal Society B: Biological Sciences, 363(1509), 3553-3561.8

6. Nainggolan Helena, R. N (2013). Faktor Yang Berhubungan Dengan Gagal Konversi Pasien TB Paru Kategori I Pada Akhir Pengobatan Fase Intensif Di Kota Medan. Medan: Universitas Sumatera Utara, (Doctoral dissertation, Tesis).

7. Fay, N., Garrod, S., \& Roberts, L. (2008). The fitness and functionality of culturally evolved communication systems. Philosophical Transactions of the Royal Society B: Biological Sciences, 363(1509), 3553-3561.8

8. Burnette, Jeni L., et al (2009). Insecure attachment and depressive symptoms: The mediating role of rumination, empathy, and forgiveness. Personality and Individual Differences, 46.3: 276-280.9

9. Nadinloyi, Karim Babayi, et al (2013). "The study efficacy of time management training on increase academic time management of students." Procedia-Social and Behavioral Sciences 84: 134-138.10

10. Osborn, Chandra Y., et al (2010). "Selfefficacy links health literacy and numeracy to glycemic control." Journal of Health Communication 15.S2: 146-158.12.

11. Osborn, Chandra Y., et al (2010). "Selfefficacy links health literacy and numeracy to glycemic control." Journal of Health Communication 15.S2: 146-158

12. Othman, N., \& Leng, K. B. (2011). The relationship between self-concept, intrinsic motivation, self-determination and academic achievement among Chinese primary school students. International Journal of Psychological Studies, 3(1), p90

13. Othman, N., \& Leng, K. B. (2011). The relationship between self-concept, intrinsic motivation, self-determination and academic achievement among Chinese primary school students. International Journal of Psychological Studies, 3(1), p90

14. Muture, Bernard N., et al (2011). "Factors associated with default from treatment among tuberculosis patients in Nairobi province, Kenya: a case control study." BMC public health 11.1: 696.

15. Morisky, D. E., \& DiMatteo, M. R. (2011). Improving the measurement of selfreported medication nonadherence: response to authors. Journal of clinical epidemiology, 64(3), 255.

16. Dobkin, Roseanne D., et al (2011). Cognitive-behavioral therapy for depression in Parkinson's disease: a randomized, controlled trial. American Journal of Psychiatry, 168.10: 1066-1074.

17. Entwistle, F., Kendall, S., \& Mead, M. (2010). Breastfeeding support-the importance of self-efficacy for low-income women. Maternal \& child nutrition, 6(3), 228-242 